\title{
Attributions through Performing Arts in the Khasi Harvest Dance
}

Natalie Jo-Anne Diengdoh, Department of Journalism and Mass Communication, English and Foreign Languages University, Shillong. Meghalaya, India natalie.diengdoh@gmail.com

(C) 2016 University of Malaya. All rights reserved.

Malaysian Journal of Performing and Visual Arts, Volume 2, 2016

\begin{abstract}
Ka Shad Ai Nguh Ïa Ki Blei, also known as Ka Leh Niam Bad Shad Ai Nguh Hima Khyrim, is a harvest dance of the Khasi tribe who inhabit the East Khasi Hills in the district of Meghalaya in northeast India. It is a calendric festival held according to the lunar position which usually falls in November or December. The festival is about attributions to the ancestors for blessing the entire district throughout the year. Ritual performances, dance and music are primary features of the festival.
\end{abstract}

Keywords: Shad (dance), Duhalia (musicians), Ka Pomblang (goat decapitation), Ïing Sad (ceremonial house of the high priestess), Hima Khyrim (traditional State named Khyrim)

\section{Introduction}

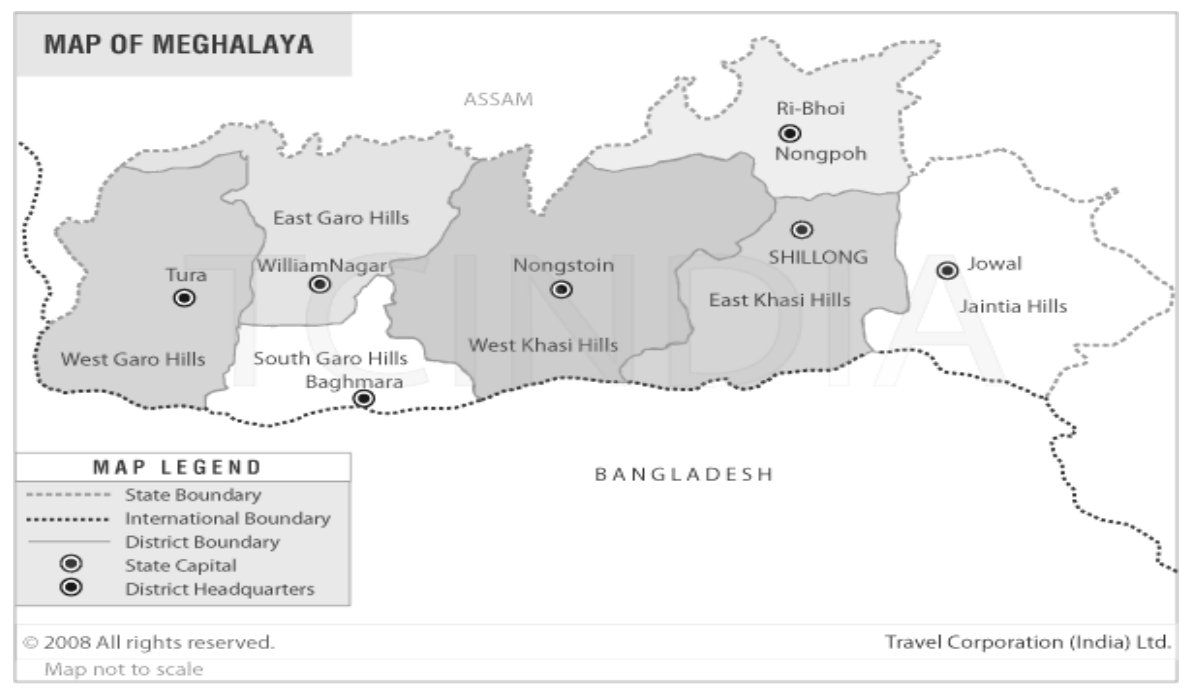

Figure 1. Map of Meghalaya 
Meghalaya is one of the Seven Sister States of India, located in the north-eastern part of the country. Meghalaya in Sanskrit and other Indo-Iranian languages means the 'abode of clouds'. It was formed by carving out two districts from the state of Assam: the United Khasi Hills and Jaintia Hills and the Garo Hills on $21^{\text {st }}$ January 1972. It is bounded to the north by Assam and Bangladesh to the south. Meghalaya covers an area of approximately 300 kilometres in length and about 100 kilometres in breadth. The capital is Shillong. As of 2011, the state has a population of $2,964,007$ and is the " $23^{\text {rd }}$ most populous in the country". ${ }^{1}$ About one third of the state is forested.

The inhabitants of the state comprise of seven diverse ethnic groups: U Khynriam (Khasi proper), also known as Nongphlang, who occupy the middle ranges of Khasi Hills, U Pnar or Synteng who live in the central plateau of Jaintia Hills, U Bhoi who are a sub-group of the Khasi community (Khasi and Jaintia), U War or Shella people who live in the south, U Maram and U Lyngngam of the west and north-west Khasi Hills who are said to be of Garo-Khasi mixture in the Lyngngam territory; and the Dko, a lost tribe believed to be assimilated under the Lyngam territory.

\section{The Legend of Hima Khyrim or Khyrim Traditional State}

Ka Shad Ai Nguh Ïa Ki Blei also known as Ka Leh Niam Bad Shad Ai Nguh Hima Khyrim or Ka Shad Bad Pomblang Hima Khyrim is an important calendric harvest festival that usually falls in November and which the Khasi celebrate with highest of pomp and fervour. There is no record of the origin of this festival probably due to the absence of a script in the pre-literate days prior to the arrival of the Welsh Calvinistic Mission in Cherrapunji who introduced the Roman alphabet in 1841. This festival is perhaps as old as society itself as it is connected with the origin of the people from the lore of Ka Pahsyntiew (one who is lured by flowers). This narrative is about a man from the Mylliemngap clan who used pumpkin flowers ('tiew jalyngkteng) to lure a beautiful damsel named Ka Pahsyntiew out of the Marai Cave situated between Pomlakrai and Nongkrem villages near the Umïew River. He secretly suspended the flowers at the entrance of the cave and when Ka Pahsyntiew tried to pluck them, he slowly approached and grabbed her hand. He then cajoled and promised to be her maternal uncle $(k \tilde{n} i)$ and that she shall be cared for as a niece. In time she bore children who became chiefs of the traditional Shillong state called Hima Shillong. Ka Pahsyntiew is also known as the goddess Syiem Blei and is the niece of 'Lei Shillong (Shillong deity), a deity who hails from Lum Shillong, which is the highest peak measuring about 1968 meters high. She is reckoned as the legendary ancestress whose attribution is connected to the origin of the chieftains or the Syiemship clan of Hima Shillong. 


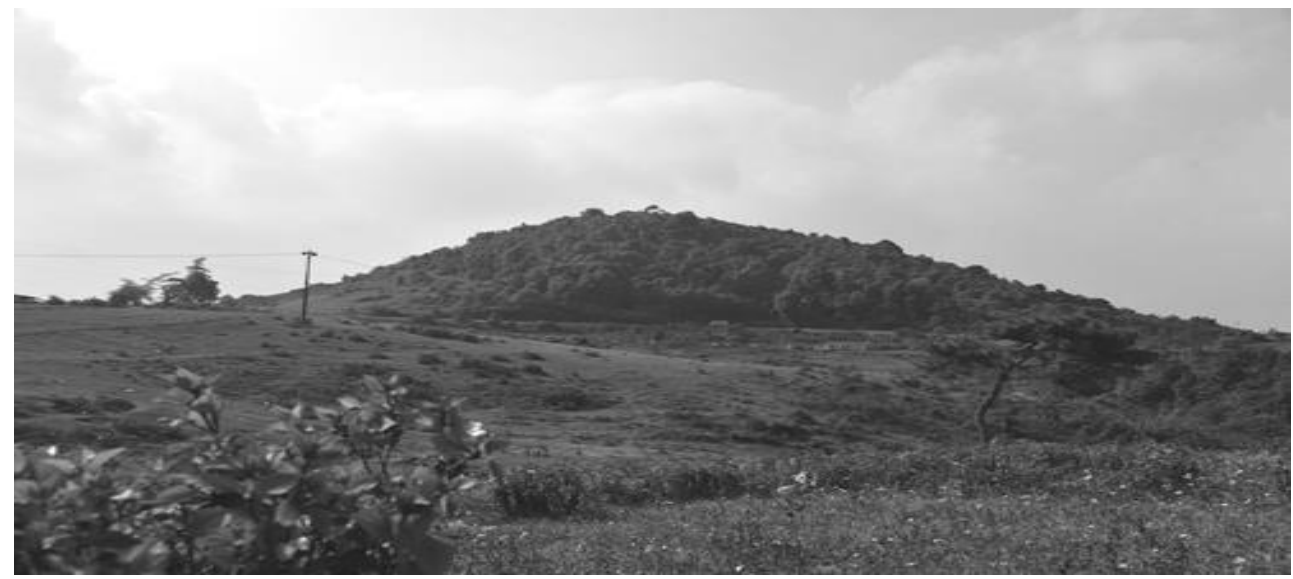

Figure 2. Marai Cave

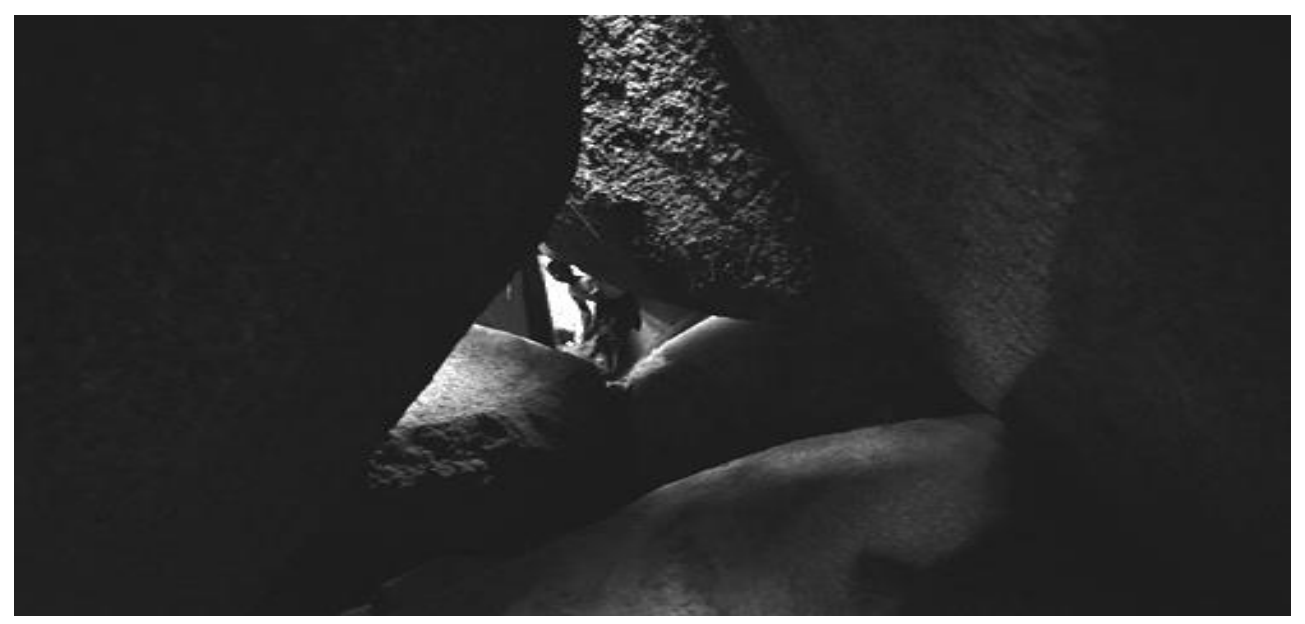

Figure 3. Lum Shillong

Prior to the bifurcation of Hima Shillong in 1853, the state comprised of Hima Khyrim and Hima Mylliem. Following the separation, Hima Khyrim or Khyrim State was given the responsibility of administration and preservation of traditional practices. Such practices are held at $\mathrm{Ka}$ Ïing Sad or the ceremonial house of the High Priestess ( Ka Syiem Sad) that was located in Nongkseh until the $14^{\text {th }}$ century after which it was moved to Smit. Traditional religious practices are conducted by the High Priestess who is the eldest daughter of the Khyrim chief ( $U$ Syiem Khyrim). It may be noted that in a matrilineal descent group the executive and judicial authority lays with the male kinusually the maternal uncle - and is prevalent in the Khasi social set up. In descent and inheritance the line passes from mother to daughter but succession to political offices is from maternal uncle $(U k \tilde{n} i)$ to nephew. 

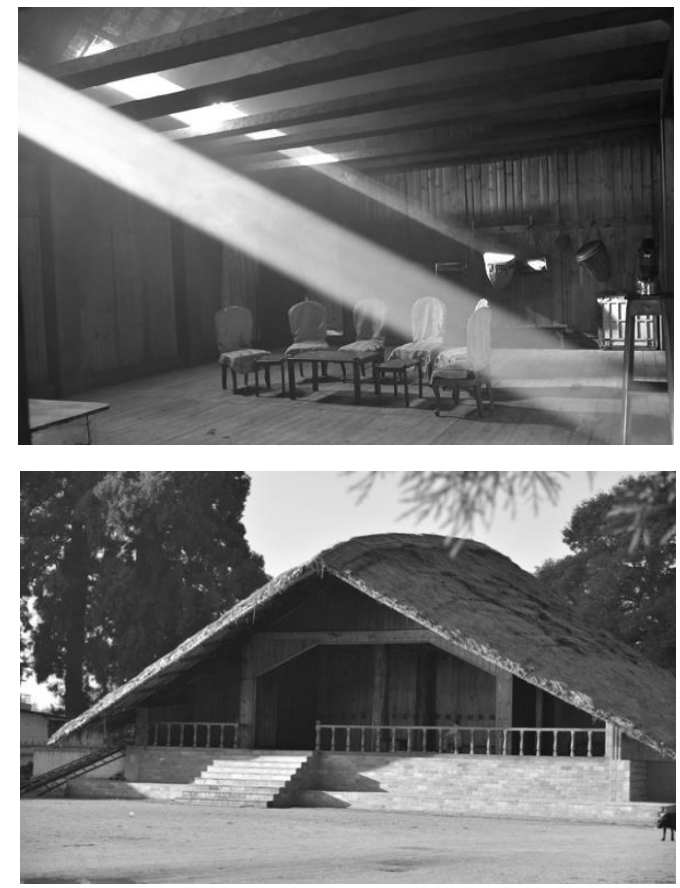

Figure 4. The exterior (above) and interior central room (Ka Shlur) (below) of the ceremonial house (Ka Ïing Sad)

\section{The Festival}

A festival is a cultural performance which is scheduled, temporary and spatially bounded, programmed, characterised by co-ordinated public occasions and heightened occasions of aesthetic expression (Stoeltje 1992). It provides opportunities to observe the communicative system of the culture, conveyed through semiotically complex performance events. Although a festival enfolds large-scale social units, there obviously occurs small-scale social interactional communication performance which constitutes face-to-face interaction. According to Stoeltje, festivals occur at calendrically regulated intervals, are public in nature, participatory in ethos, complex in structure, and multiple in voice, scene and purpose. They are collective phenomena and serve purposes rooted in group life. Systems of reciprocity and of shared responsibility ensure the continuity of and participation in the festival through the distribution of prestige and production (Stoeltje 1992, p. 261). The festival performance serves the purpose of the articulation of a group's heritage; it is a communicative situation actively engaging participants, presenting a combination of participation and performance in a public context.

The festival site is at Smit village the capital of Khyrim State. Ritual performances are held within the periphery of the ceremonial house. The house itself is a big thatched house made of wood and bamboo with no supply of electricity and use of iron, for use of wood on wood is considered auspicious to the State. Natural light that penetrates through small glass squares in the thatch overhead the central room (shlur) of the house 
is the only source of illumination during the day, which are substituted by lanterns by night.

This festival is celebrated on particular market days called Rynghep, Shillong, Pamtiah, Umni, Ïewduh, Lyngka and Pynshing. Pamtiah marks the start of ritual performances and the last day is called Pynshing. The Khasi have a unique style of calculating time which is closely associated to nature. Reference to the moon or lunar month ( $U$ bnai) is significant in agriculture and cultural and ritual performances as it forms the basic reckoning of days of the week. Khasi markets ( $\ddot{I} e w$ ) are associated with names of places; it may be mentioned that a market takes place only once a week in a particular place. A Khasi week consists of eight days, each matching to their respective locations:

1. İew Lyngka (Lyngka market) - Barapani in East Khasi Hills District and Khawang in Jaiñtia Hills District

2. Ïew Nongkrem (Nongkrem market) - Nongkrem Village in East Khasi Hills District

3. Ïew Umlong (Umlong market) - A small market in Shillong adjacent to the Ïewduh or main market in East Khasi Hills District

4. Ïew Rynghep (Rynghep market) - Occurs in three locations at Ïewbah in Cherrapunji Syiemship (State), Mawtawar in Mylliem Syiemship and at Umsaw in Nongkhlaw Syiemship in East Khasi Hills District

5. Ïew Shillong (Shillong market) - Laitlyngkot Village in East Khasi Hills District

6. $\quad$ Iew Pamtiah (Pamtiah market) - Used to take place in a small market in Mawkhar in East Khasi Hills District and Pynkat in Mynso - Jaiñtia Hills District

7. Ïew Umni (Umni market) - Umsning Ri-Bhoi District and Thymbleiñ in Jaiñtia Hills District

8. İewduh (Iewduh market) - The biggest market takes place in Shillong, East Khasi Hills District and in Jaiñtia Hills District. It is known as ka hat in Jaiñtiapur (Jaiñtia Hills District)

\begin{tabular}{|l|l|l|l|l|l|l|}
\hline $\begin{array}{l}\text { Sngi Ïew } \\
\text { (market } \\
\text { days) }\end{array}$ & Places & $\begin{array}{l}\text { Ha Ri Lum } \\
\text { Mihngi } \\
\text { (Places in the } \\
\text { East) }\end{array}$ & $\begin{array}{l}\text { Ha Ri Lum } \\
\text { Pnar } \\
\text { (Places in } \\
\text { the Pnar) }\end{array}$ & $\begin{array}{l}\text { Jowai } \\
\text { (Places in } \\
\text { the Jowai) }\end{array}$ & $\begin{array}{l}\text { Bhoi } \\
\text { (Places in the } \\
\text { Bhoi) }\end{array}$ & $\begin{array}{l}\text { Sepngi } \\
\text { (Places in } \\
\text { the West) }\end{array}$ \\
\hline Ïewduh & Shillong & $\begin{array}{l}\text { Laban/ } \\
\text { Langkyrdem }\end{array}$ & $\begin{array}{l}\text { Borkhat/ } \\
\text { Nongjngi }\end{array}$ & Hat & Umshohphira & Raqngblang \\
\hline Lyngka & Nongstoiñ & $\begin{array}{l}\text { Tyrsad/ } \\
\text { Laitkynsew }\end{array}$ & $\begin{array}{l}\text { Sutnga/ } \\
\text { Dawki }\end{array}$ & Khyllaw & Mawhati & $\begin{array}{l}\text { Nongstoiñ/ } \\
\text { Mariot }\end{array}$ \\
\hline Nongkrem & Pynursla & Shella/Mawsmi & $\begin{array}{l}\text { Wahiajer/ } \\
\text { Rymbai }\end{array}$ & Pynsin & Umden & $\begin{array}{l}\text { Rymbrai/ } \\
\text { Myriaw }\end{array}$ \\
\hline Mawlong & Nongpoh & $\begin{array}{l}\text { Mawsynram/ } \\
\text { Lyngkhat }\end{array}$ & $\begin{array}{l}\text { Nartiang/ } \\
\text { Raliang }\end{array}$ & Mulong & Nongpoh & $\begin{array}{l}\text { Makasa/ } \\
\text { Ingding }\end{array}$ \\
\hline
\end{tabular}




\begin{tabular}{|l|l|l|l|l|l|l|}
\hline Rynghep & $\begin{array}{l}\text { Jowai/ } \\
\text { İawmusiang }\end{array}$ & $\begin{array}{l}\text { Sohra/ } \\
\text { Lyngkyrdem }\end{array}$ & $\begin{array}{l}\text { Jowai/ } \\
\text { Ïawmusiang }\end{array}$ & Musiang & $\begin{array}{l}\text { Mawlanai/ } \\
\text { Patharkhmah }\end{array}$ & $\begin{array}{l}\text { Umdohlun/ } \\
\text { Nongum }\end{array}$ \\
\hline Shillong & Mawkyrwat & Laitlyngkot & $\begin{array}{l}\text { Shangpung/ } \\
\text { Dawki }\end{array}$ & Muchai & Umroi & $\begin{array}{l}\text { Mawkyrwat/ } \\
\text { Nongkhlaw }\end{array}$ \\
\hline Pamtiah & Mawryngkneng & $\begin{array}{l}\text { Mawngap/ } \\
\text { Shella/ Pynursla }\end{array}$ & Mynso & Pyngkat & Tyrso & Kynshi \\
\hline Umni & $\begin{array}{l}\text { Mairang/ } \\
\text { Langstieh }\end{array}$ & Lyngkhat/ Smit & Muktapur & Thymbleiñ & Umsning & $\begin{array}{l}\text { Langstieh/ } \\
\text { Maweit }\end{array}$ \\
\hline
\end{tabular}

Table 1. Market Days (Ki Sngi Ïew Heh)

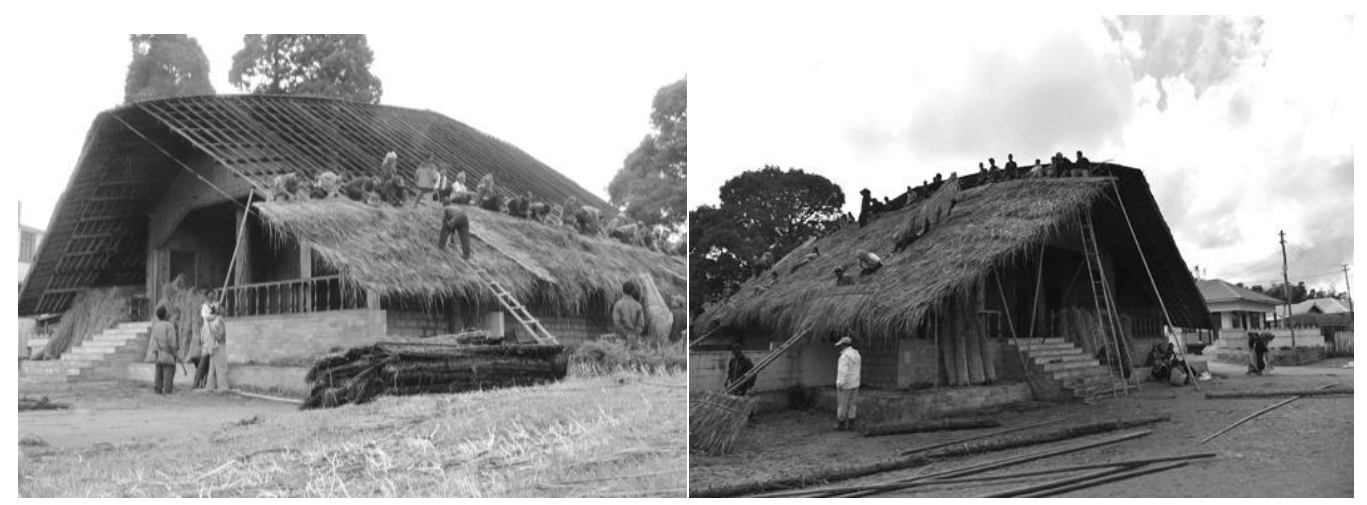

Figure 5. Ka Sop Ïing Sad in 2014 (left) and 2015 (right)

The festival begins with the ancient tradition of replacing the straw of one side of the ceremonial house's roof ( $k a$ sop $\ddot{i} a$ ka ïing sad). This is done on a specific market day called Ka Sngi Ïew Rynghep. One side of the roof is replaced annually. It may be noted that the customary practice of changing and adding finishing touches must be completed by the end of Ka Sngi Ïew Rynghep. The ceremonial house ornamented with fresh thatch marks the start of performances in Khyrim State. Before the existing straw is removed from the roof, a ritual performer or priest from the Mawroh clan ( $U$ Sohblei Mawroh) removes the thatch (satep) at the ridge of the ceremonial house's roof. The replacement straw is collected from all corners of the State. Traditionally, the straw brought from Rasong Rongphlang villages is first welcomed at the house, followed by straw from Ri-Bhoi district and other villages of the state. The sequence has been maintained since ancient days and no significant distinctions were noticed. De-weeding and bundling of the straw is done by male and female members from the Nongbri clan. It may be noted that the annual customary practice of replacing the roof's straw is a voluntary service rendered by inhabitants of Khyrim State.

Thence, at noon on a Shillong market day (Sngi Ïew Shillong), ten to eleven musicians (duhalia) along with volunteers of the state proceed to Umiew River to cleanse the ritual paraphernalia such as swords, brass ampules, baskets and so on. This day is 
known as the washing of drums ( $k a$ sait ïa ka bom bad ki ksing) though there is no part where drums are washed except for its use to symbolically announce the inhabitants of the state when participants head towards the river for washing and on their return to the ceremonial house.

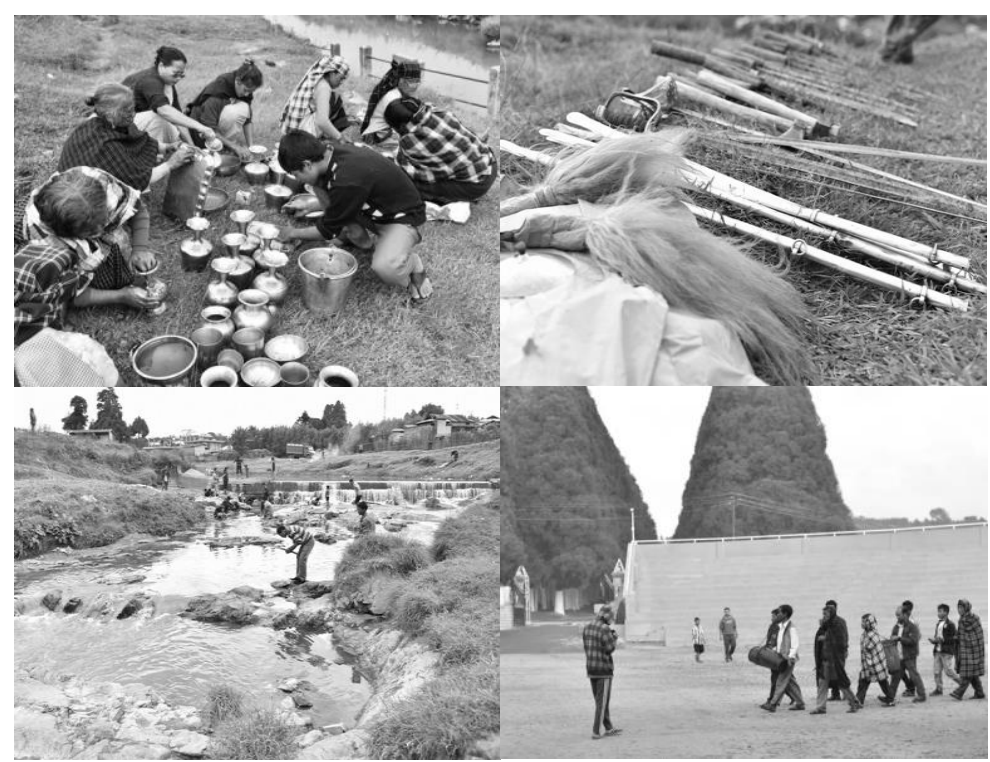

Figure 6. Washing of drums (Ka Sait Ïa Ka Bom Bad Ki Ksing)

From this day on the musicians reside at the ceremonial house until the end of the festival. During their stay they practice to perfect various religious tunes and drum beats (skit sing niam) every evening until late at night at the veranda (tyngkong) of the ceremonial house. The musical instruments they use include a big drum (bom), two drums (ksing), a female drum (ksing kynthei), a flageolet (tangmuri) - which is the queen of Khasi musical instruments - a cymbal (kynshaw) and a small drum (padiah), all of which echo in the neighbourhood. Percussions reverberating from the ceremonial house mark the beginning of the joyous occasion. Maintenance in terms of food, drink, shelter, clothing and remuneration is taken care of by the Chief of Khyrim State ( $U$ Syiem Ka Hima Khyrim). 


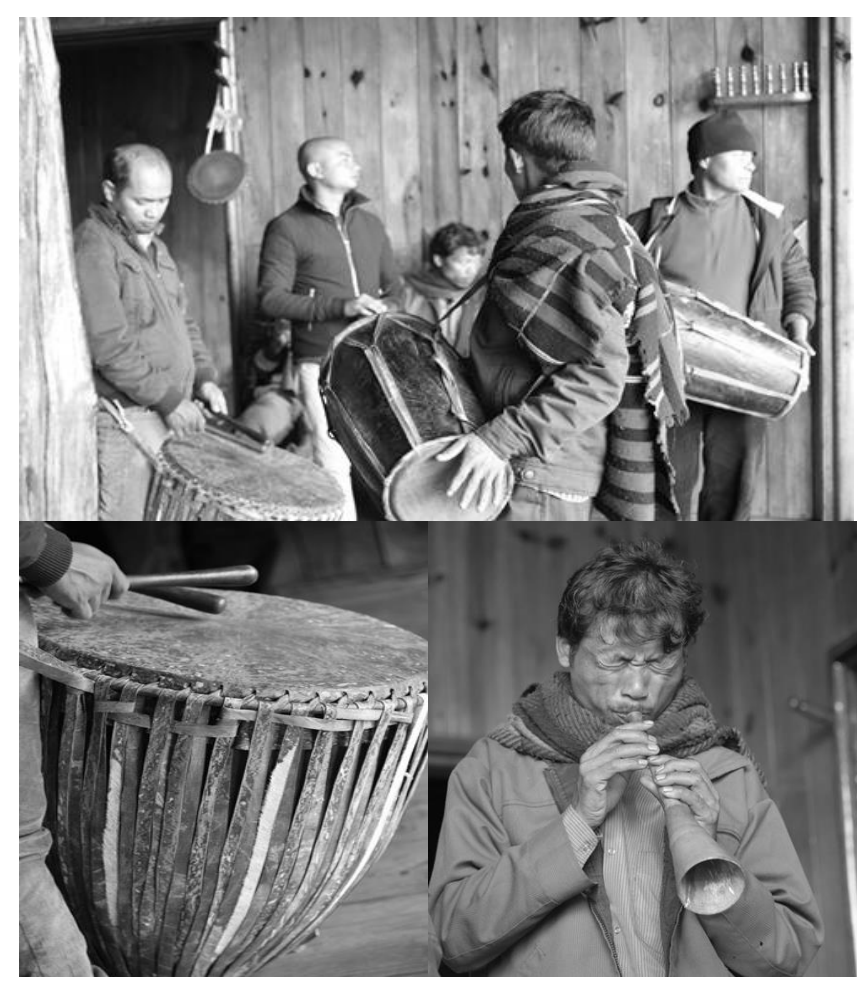

Figure 7. Musicians rehearsal (above) which includes instruments such as the bom (bottom left) and tangmuri (bottom right)

Pamtiah - The first day and beginning of sacred ritual performances is called Ïew Pamtiah. Before sunrise and prior to the chirping of birds and herald of the rooster, musicians position themselves at the veranda of the ceremonial house and sound only the big drum to announce the official start of ritual performances at the ceremonial house. The drum beats throb until sunrise after which the High Priestess and Head Priest (U Sohblei) step on the central room where the sacred or God's pillar (U Rishot Blei) stands tall. The God's pillar is enveloped in bamboo matting with Khasi oak (diengsning) wrapped in fresh white cotton yarn tied at the upper portion of the pillar and a picket fence around its base. The pillar is an allegorical link between heaven and earth derived from the lore of the golden ladder ( $k a$ Jingkieng Ksiar) and the diengiei tree. It is customary for the High Priestess and Priest to complete all religious performances at the ceremonial house since bifurcation: the High Priestess is the custodian of all traditional customary performances and while the Head Priest conducts all religious performances. Every year the old Khasi oak tree is replaced with a new one that is tied to the God's pillar by a priest from the Mawroh clan ( $U$ Sohblei Mawroh) after it is prepared by the Head Priest.

Later in the evening, the High Priestess begins the rituals by paying homage to ancestors and ancestress with the use of rice-beer (iad-um or jyndem) along with the head priest from the Rumnong clan (U Sohblei Rumnong) at the kitchen of the ceremonial house (Ïingbah). On this auspicious occasion he is assisted by the Mawroh clan priest. The two clan priests light wax sticks for each other when performing religious rites. It is observed during the ritual performance that attributions are made to 
the God of Shillong (U Blei Shillong) or U Thawlang of the lore of Ka Pahsyntiew, or Ka Blei Long Syiem- Pahsyntiew (also known as Ka İawbei) who is the first mother of the Syiem clan and of the first chief, or U Suidñia Long Syiem who is the first maternal uncle of the Chief and the first Chief of the Syiem clan. Music forms the criterion corresponding to the synchronicity or religious tune of individual ancestors ( $k i$ skit niam).

On completion of all rituals the musicians conclude their drumming and everyone enter the central room of the ceremonial house. When all the participants have assembled in the central room the musicians begin the rice beer ritual to the God of Art (U Biskorom). The oldest member perform a ritual from one jar along with prayers which is repeated three times before all the musicians partake the rice beer and ten different drum beats and twenty six tunes of Pomblang or religious tunes (sing niam) are played. On completion of all religious performances everyone in the room receives roasted dried fish (ka suit dohkha or sam khapiah kaba la thang). This is followed by a dance performed by only male members called ka shad tyngkoh. The dried fish is distributed thrice to everyone present at the central room. Bamboo sticks are lit as a source of light. The Eldest Chief (Syiem Rangbah) and the musicians then perform the drums for exalt (sing-risa), which is done nine times. This is followed by a tune meant for a dance called Sohtyngkoh (sing-shad tyngkoh) where men from the noble clan of the territories first offer thanks to the God's Pillar and the Eldest Chief and nobles perform the Sohtyngkoh dance in pairs. These dancers are:

1. The Priest and one of the musicians

2. The noble from Nongkrem and Nongbri clans

3. The noble from Mawlieh and Mawshai villages

4. The noble from Nongkynrih and Lawai clans

5. The Eldest Ruler and the Youngest Ruler

Whenever the nobles dance, the musicians use the male drum, one smaller drum and the cymbals along with the flageolet. When the Chief dances they use the female drum instead of the male drum and all present exalt three times.

Umni - The second day begins at the crack of dawn prior to the rising of the sun when musicians sound the religious drum beats. During the day on arrival of participants of varied age groups, there is the traditional procession of cleaning and paving the path (soi lynti) from the right of the religious altar at the ceremonial house to a hilltop called Lum İewduh where the decapitation of goats takes place. As the procession to the hill top commences, the drum beat for a sword dance ( $k a$ sing shad wait) is played by the musicians and dancers move to the beat of the music in a sequence which could be termed as a rhythm-less dance ( $k a$ shad lymmuh). Cleansing of the pathway and the dance arena (lympung) at the hill top is done before commencement and on completion of ritual performances.

For decades the Lum Ïewduh hilltop has been designated for this religious performance. At the hill top after sacrificial offerings are complete a warrior dance by the men folk (mastieh) marks the end of the ritual performance. On their return to the 
ceremonial house, musicians play the marching drum beat (sing mastieh) at the veranda and men from the noble clan perform the Mastieh dance in pairs at the arena of the ceremonial house.

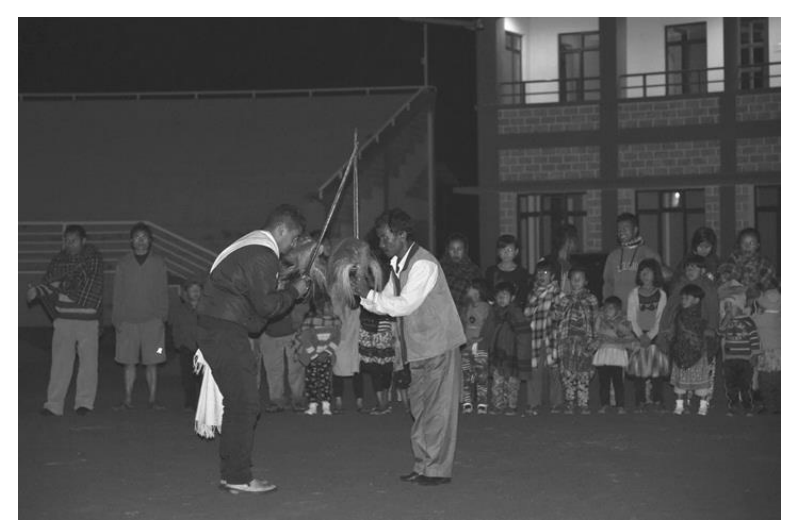

Figure 8. Sword dance (Ka shad Mastieh)

Ïewduh - In the morning of the third day the Eldest Chief distributes clothes (jaiñ) to the musicians comprising of a shirt ( $k a$ sopti), silk or cotton dhoti ( $k a$ boh khaila) and a turban ( $k a$ jaiñspong). The elder musicians are given silk turbans and the young musicians are given cotton ones. At midday clothed in traditional attire the musicians perform the sword dance in pairs to the tune of religious drum beat. After the dance the Eldest Chief distributes five pieces of areca nuts and beetle leaves smeared with some lime on the beetle leaf from a special silver container (dabia rupa) to the elder musicians.

At sundown the High Priestess packs a conical cane basket (khoh) with items required for the ritual performance at the hilltop for decapitation of goats or Ka Pomblang. The procession to the hilltop starts from the central room of the ceremonial house with musicians playing the pathway beat (sing lynti) up to the doorway. Following the lead is the head priest, the bearer of the cane conical basket, young priestesses, Chief, Nobles and crowd. As the procession proceeds the sword dance drum beat is played while male dancers dressed in traditional attire whisk their yak's tail (sympiah) and sword (waitlam) accompanied by fires of gunpowder to ward off evil spirits along the way. 

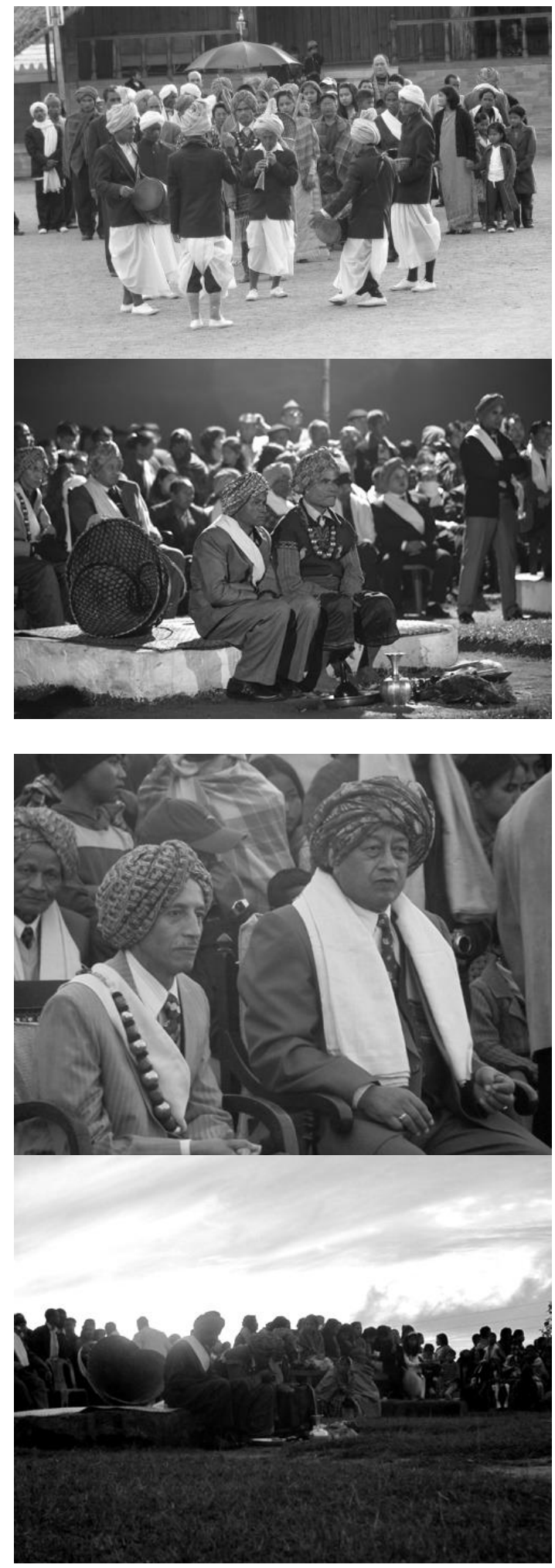

Figure 9. Procession to Lum Ïewduh (above) followed by religious performance (below)
Figure 10. The Eldest Chief and a noble (above) await the religious performance (below) 


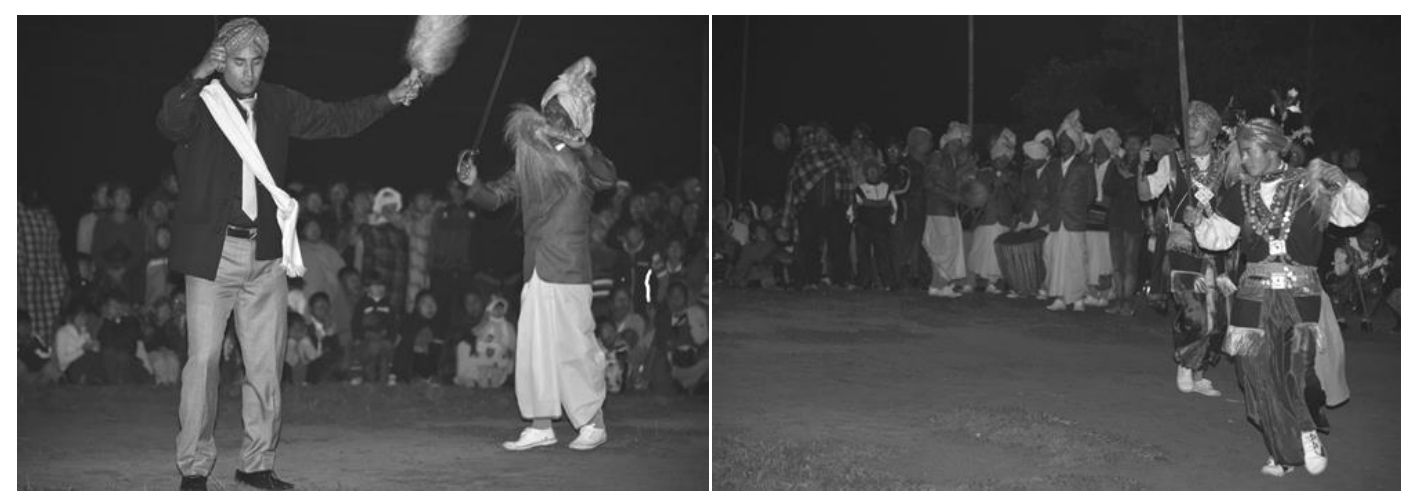

Figure 11. Sword dance (Mastieh) at Lum Ïewduh

On reaching the hilltop, the musicians change the drum beat to the pathway drum beat. The musicians enter the arena by circling the specially-made altar three times. After they have taken their position, the priest enters the scene and sits on a mat in front of the altar. The female members of the clan sit on the west side of the altar and the Eldest Chief in the east, while the nobles stand on his right, left and behind him.

Mention must be made that all ritual performances at the make-shift altar at the Lum Ïewduh hilltop is done with utmost precision and sanctity to the Shillong Deity to bless and keep the Chief (U Syiem-Patsha), the state and its territories (Ka Hima Sima) and their subjects (ki khun ki hajar). After all the sacrificial offerings are complete the musicians play the marching drum beat followed by the sword dance at the hilltop in pairs and in the same manner as on the Umni day. This also includes the dance by the Eldest Chief and one of the Nobles while the men fire their powdered guns in the air. When all is over the musicians once again circle the altar three times and play the pathway beat and dance all the way back:

The dances that followed were male-only. Two teams of six dancers came forward in pairs. They placed their swords on the altar stone, made obeisance to the Syiem (Chief) and Sohblei (head priest), and then, taking up their swords, initiated the protracted shad mastieh (dance of the men). This was a sequence of war dances involving cock-like scuffing of the turf, boastful prancing with swords and whisks and stylized feints and lungs. ${ }^{2}$

At midnight the marking and explaining of goats known as ka bujai blang, gifted for the occasion by inhabitants of the state, are received and kept overnight in a shed (kynram blang). The Eldest Chief sits in the west along with the Nobles and state officials. The goat givers and the public stand at a corner in the east while one of the musicians and the Chief's servant stand at the back door (shahksew) near the shed. The first of the male goats from the Chief's clan and nobles ( $k i$ 'lang-sla and $k i$ 'langshynrang) are received followed by those gifted by the territories and last of all those gifted by the villagers ('lang shi-khlieh). When the marking of goats is over, the Eldest Chief and everyone enters the central room where they partake the boiled meat of the goat brought from the hilltop three times ( $u$ lang Ïewduh). Then the musicians play the 
drums of exalt and everyone exalt nine times and dance to the tune of the male-only dance.

Lyngka - The fourth day or Lyngka market day is a day for subjects and children of the Syiem clan to enjoy and display their traditional Khasi dance ( $k a$ shad Khasi). In fact the festival is well known for this day due to public participation in terms of dancing and spectatorship.

After religious performances at sunrise maiden priestesses set the first foot step of the dance known as Ka Shad Nohkjat at the central room of the ceremonial house. Dressed in royal traditional attire they are draped in golden shawls (khor), golden crown (pansngiat ksiar) and gold threads to hold hair buns and gold jewelry, they perform the first footstep dance ( $k a$ shad nohkjat) to the rhythm of the female drum beat ( $k a$ 'sing kynthei). The maiden priestesses (ki Syiem) are placed in the center accompanied on either side by male members of the family, nobles and two elder musicians. This is then continued at the dancing arena and at the arena musicians are placed in the center and dancers circle around them. The crowd (ki paidbah) also perform the dance for male and female dancers (kynthei bad shynrang ki shad).

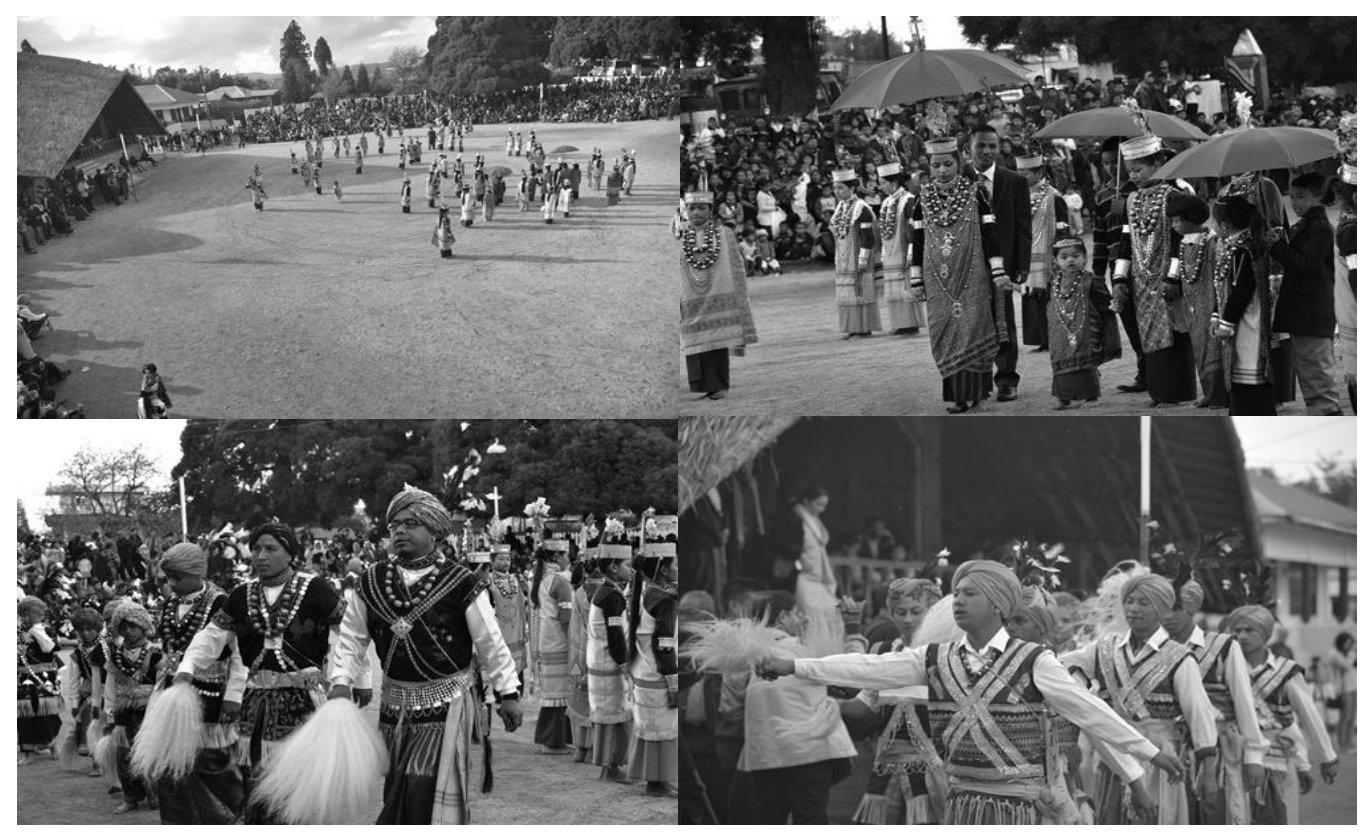

Figure 12. Ka Shad Ai Nguh Ia Ki Syiem or Nongkrem dance

Female dancers dancing at the centre of the dancing arena (lympung) are clad in traditional attire adorned with golden silk wraparounds ( $k i$ jaiñ pieñ khor), yellow dhara (sem da ki dhara stem), velvet blouses (sopti kti mokmor), a silver crown (pansngiat rupa), a sweet-scented yellow lasubon flower tied with mixed-coloured flowers made of cloth (tiew lasubon ba la teh ryngkat bad ki syntiew jaiñ ba bun rong) to symbolise purity, a silver thread to tie hair buns ( $u$ sai khyllong rupa), a necklace ( $u$ 
shan ryndang ne konopad ksiar ki deng ha ryngdang), gold earrings (ki lyngkyrneng ne ki 'siarshah ne ki 'siar kynthei ki deng ha shkor), silver armlets (ha ksang kti ki tad tyrpeng rupa) and gold finger rings ( $k i$ sati ksiar). Male dancers wear a traditional waist coat (jymphong), a golden turban (jaiñspong da ka khor) with an 18-inch plume worn on their turbans ( $u$ thuia), a silk dhoti (boh khaila dhara), gold earrings (siar shrong ha shkor) and a necklace (shanryndang or shanrang). Around the arm they wear a silver armlet (tad tyrpeng rupa) together with silver waist chain ( $u$ kynjri syngkai rupa). They drape a silver quiver with three silver arrows (ka ryngkap rupa shadien ha kaba la sieh lai tylli ki khnam rupa) around their shoulders and affix feathers of a long-tailed black bird which imitates the cries of other birds (ki sner $u$ rynñiaw ba teh $u$ tdong) on the turban. On the chest, they wear a silver breast piece (kynjri tabah rupa) and one round of coral-beaded necklace (shiwat u kpieng). Holding a yak's tail on the right hand, they dance until sunset.

A human circle is formed by the male dancers around the female dancers, often depicted as protection for the women folk, an allegory of the Khasi matrilineal society. With grace, bare-footed girls move within the circle in sync, forward and backward (a typical traditional dancing style of the Khasi women). With swords in their right hand and a white yak-hair whisk on the left hand, the male dancers move in rhythmic tempo - advancing, hedging and retreating to the beat of the drums. After sunset, the religious performances ( $k a$ leh niam) and Ka Pomblang begins, followed by the male sword dance at the arena.

Pynsing - At mid-day of Pynsing or Ïew Nongkrem on the final day, the musicians go to the ceremonial house to receive a basket of cowry or coins (bai duhim). This is reward for the services rendered by the musicians during the festival. While heading back to the musicians' hut they play the pathway drum beats. Another religious drum beat is also played at the end along with the state officials before they consume the rice and mutton curry made of a goat meant for the musicians only. After the feast they play the drums of merriment (sing risa bah) and exalt nine times. They receive betel nut (bhet) given by the members of Mawlieh and Mawshai clans and enter the hut of the Head Priest for consumption of rice beer and traditional rice (jadoh) prepared from the goat gifted by the Chief.

It is believed that performances at the festival have been done with no alteration in the protracted and complex rituals for perhaps hundreds of years. It is an exuberant ceremonial art with high religious purpose and deep social meaning. Traditional performances in dance, music, symbols, verbal art, rituals etc. are learnt through many years of apprenticeship by assisting their superiors, uncles and mothers and are performed under strict supervision of the elders. These traditions are heard, stored in memory and when appropriate recalled at the moment of subsequent transmission. Specific religious performances denote detailed connotations and all rites are not open for public viewing or participation. These cultural objects and properties are generally kept in secret with the knowledge of keeper/performer only by observing several restrictions. Since the festival is meant for the state's inhabitants and participants in 
terms of dance are open ended, meaning all are welcome irrespective of religious denomination.

Mention must be made that the variations in terms of the Khyrim State's rhythmic tunes played during the festival maybe termed as authentic traditional music of the Khasi yore. Drum beats ( $k i$ skit) may be identified as non-religious beats (ki skit rong) and religious rhythmic pattern of music (ki skit niam). The non-religious beats comprise of lumpaid, mastieh, shad wait, padiah ardieng, sing sohtyngkoh and sing risa. The religious rhythmic pattern of music incorporating 10 drums (shiphew ksing) and 27 rhythmic patterns (arphew hynñiew skit) are played throughout the festival. They are timed with precision denoting essential attributions of homage to deities such as the God of Art performed before sunrise on Umni market day and the Goddess of Governance (Ka Lei Synshar) before the herald of the rooster at dawn on Ïewduh market day are minute examples. It is observed that during the ritual performance at Pamtiah and Umni market days, sections of individual tune perfectly coordinated alongside ritual performance are strictly maintained.

Based on the age old tradition, elements of little tradition identified with its legitimate forms at the festival could circulate upwards to the level of the Great Tradition. Great tradition is a body of knowledge which functions as the beacon light of knowledge. It originates by universalization or a carrying forward of materials which are already present in the Little Tradition which it encompasses (Mckim Marriot. 1955).

While adherence to traditional performances is maintained, its representations could be world renowned. Performances from selected sections of rites and rituals, dance which is the very essence of matrilineal system of the Khasi, traditional costume which are ancient heirloom and various rhythmic pattern of music are fundamental ideas of the Great Tradition. Mention must be made that Diwali and Raksha Bandhan have their origin in little tradition. Diwali or Deepavali meaning "series of lights" is derived from dippa (light or lamp) and 'āvali' (series, line or row). It is also known as dipotsava meaning "festival of lights". Diwali dates back to ancient times in India, as a festival after the summer harvest in the Hindu calendar month of Kartika, named after a Hindu God. The festival is celebrated in autumn in the northern hemisphere (spring in southern hemisphere). Raksha Bandhan, also called Rakhi Purnima or simply Rakhi in many parts of India and Nepal, meaning "bond of protection" or "the tie or know of protection", is a Hindu religious and secular festival. The festival celebrates the love and duty between brothers and sisters. The word raksha means protection, while bandhan is the verb "to tie". It is an ancient Hindu festival that ritually celebrates the love and duty between brothers and their sisters. The sister performs a Rakhi ceremony, then prays to express her love and her wish for the well-being of her brother; in return, the brother ritually pledges to protect and take care of his sister under all circumstances. It is one of the several occasions in which family ties are affirmed in India. The festival is also observed by Jains as a religious festival, as on Raksha Bandhan, Jain priests give threads to devotees. The festival is also an occasion to celebrate brother-sister like family ties between cousins or distant family members, sometimes between biologically unrelated men and women. To many, the festival 
transcends biological family, brings together men and women across religions, diverse ethnic groups and ritually emphasizes harmony and love. It is observed in the Hindu calendar month of Sravana, and typically falls in August every year.

Worldwide genres of folklore are undergoing a "paradigm shift" 3 where expressions of traditional cultural performances or folklore are affected at both tangible and intangible ways. The impact of urbanization and globalization has brought about significant changes in the dimensions of folklore. These noticeable changes have found their niche that has managed to receive acceptance, tolerance, adaptation and innovation at $\mathrm{Ka}$ Shad Ai Nguh Ïa Ki Blei or Nongkrem Dance Festival. In the present day, modern means of mass media such as print (newspapers, hoardings, banners) and the electronic media (television, radio and internet) are employed to inform the mass about the festival. A portion of green grassy foothill surrounding the dancing arena is replaced by concrete walkway. Artificial traditional getup have replaced the expensive 24 karat gold of the dancers. The official banning of rice beer usually sold by local vendors in the open space and so on is a subtle observable change at the festival which has resulted in the birth of a cross-culture interface of traditional performance combined with modernization that may perhaps be termed as the paradigm shift of the festival.

In conclusion, Ka Shad Ai Nguh Ïa Ki Blei comprises of semiotically complex performance events. The festival provides the scenery for the interplay of tradition and innovation in communicative social life. The created communicative situation reflects shared experience of the group, promotes social revitalisation, and celebrates ethnic identity in the context of cultural expression. The festival brings people together and communicates about the society.

\section{Endnotes}

${ }^{1}$ Meghalaya Population Sex Ratio in Meghalaya literacy rate data (Census 2011.co.in).

${ }^{2}$ Bhargava, ed. S.C. Bhatt, Gopal K. 2006. Meghalaya. Delhi: Kalpaz publ. ISBN 8178353741.

${ }^{3}$ Sen, Soumen. 2010. Folklore Tradition Urbanity. Anjali Publishers. Kolkata. p. 139

\section{Bibliography}

Bareh, H. (1997). The History and culture of the Khasi People. Gauhati: Spectrum Publications.

Chowdhury, J. N. (1978). The Khasi canvas: A cultural and political history. India: Chapala Book Stall. 
Elias, H. (1972). Ki Khanatang U Ba Rim. Shillong: Don Bosco Press.

Gurdon, P. R. T. (1997). The Khasis. Delhi: Cosmo Publishing

Jhingan, P. (2009). The Khasi theatre: A semiotic study of the Nongkrem dance festival. Delhi: Academic Excellence.

Karlsson, B. G. (2010). Unruly hills: A political ecology of India's northeast. New York: Berghahn Books.

Lyngdoh, H. (2008). Ka Pomblang Nongkrem ki Mawbynna Ki Jait Syiem bad Ki Jait Lyngdoh. Shillong: Desmond P. Diengdoh

Lyngdoh, M. P. R. (1991). The festivals in the history and culture of the Khasis. New Delhi: Vikash Publishing House Pvt. Ltd.

Mawrie, H. O. (1981). The Khasi Milieu (Trans. Sujata Miri). Delhi: Concept Publishing Company.

Mawrie, O. H. (1981). The Essence of the Khasi Religion. Shillong: RiKhasi Press.

Chaudhari, A. B. \& Sarkar, D. D. (2003). Megadiversity conservation: flora, fauna, and medicinal plants of India's hot spots. Delhi: Daya Publishing House.

Sen, S. (1985). Religion and Culture: The Khasi-Jaintia Experience. Proceedings of the Sixth Session of North-East India History Association. J.B. Bhattacharjee (Ed.).

Shillong: NEIHA. pp. 109-110, 113

Roy, H. (1982). Where Lies the Soul of our Race. Seng Khasi Series, No. 2.

Singh, N. (Ed.) (1983). Khasi-English dictionary. Delhi: Cultural Publishing House,

Syiem, S. (2002). Ka Jinglehniam Ka Hima Khyrim. Shillong: Plinsimai Syiem, Ri Khasi Enterprise.

\section{Interpersonal communication}

Badriti Syiem, Syiemsad of Hima Khyrim

Dr. Balajied S Syiem, Syiem of Hima Khyrim

A. Diengdoh, Kongor of Hima Khyrim 
Malaysian Journal of Performing and Visual Arts, Vol. 2, Dec. 2016

Twinklestar Diengdoh, Resident of Saitsohpen, Cherrapunji

P. Diengdoh, Resident of Saitsohpen Cherrapunji

Participants and audience of Ka Pomblang Nongkrem or Ka Shad Nongkrem

\section{Website}

http://megh-ac.nic.in

http://www.khasilit.org 